\title{
Grawitz 腫瘍の舌根転移例
}

$\begin{array}{lllr}\text { 小田 } & \text { 一成・立川 } & \text { 隆治・川口 } & \text { 和幸 } \\ \text { 福島 } & \text { 典之・平川 } & \text { 勝洋・鈴木 } & \text { 衞 } \\ \text { 夜陣 } & \text { 紘治・原田 } & \text { 康夫 } & \end{array}$

\section{Metastasis of Grawitz's Tumor to the Tongue ; A Case Report}

\author{
Kazunari Oda, Takaharu Tatsukawa, Kazuyuki Kawaguchi, \\ Noriyuki Fukushima, Katsuhiro Hirakawa, Mamoru Suzuki, \\ Koji Yajin and Yasuo Harada
}

(Hiroshima University)

\begin{abstract}
Grawitz's tumor metastasizing to the tongue is very rare. Only six cases have been reported in Japan. We treated a patient with Grawitz's tumor metastasizing to the base of the tongue. The patient is a 66-year-old male with a complaint of dysphagia. He had undergone left nephrectomy for Grawitz's tumor six years earlier, Cryosurgery was performed to reduse the mass of the tongue, but he died of pulmonary metastasis six months later.
\end{abstract}

Key words: Grawitz's tumor, tongue metastasis, cryosurgery

\section{はじめに}

頭頸部領域では, 頸部リンパ節以外への悪性 腫瘍の転移は少ない。今回我々は, Grawitz 腫 瘍で左側腎摘出後に肺転移をきたし化学療法中 飞舌根部腫瘍が出現し，組織診にて Grawitz 腫瘍の転移が証明された一例を経験したので， 文献的考察を加光て報告する。

\section{症例}

患者：66歳，男性.

主訴 : 曣下障害.

家族歴・既往歴 : 特記すべきことなし.

現病歴：1983年 2 月より無症候性血尿のため, 同年 3 月に当院泌尿器科で, 左側腎原発の Grawitz 腫瘍の診断のもとに, 左側腎摘出術拉
よび傍大動脈リンパ節郭清術をらけた。その後, 1985年 2 月に肺転移のため，インターフェロン と抗癌剤による治療を受けていた。1988年12月 から嚥下障害が出現したため，1989年 1 月 4 日 に近医耳鼻科を受診し，右舌根部腫瘍を指摘さ れ，同年 1 月 9 日精査目的にて当科を受診した. 初診時所見：間接喉頭鏡検査で，右舌根部か ら右喉頭蓋谷にかけ腫瘍を認めた。腫瘍の表面 は, 赤く一部突出し, その中央は, 壊死を起こ し白苔が付着しており易出血性であった。頸部 の触診では，右顎下部に硬い腫瘤を触知した。

検査所見：頸部 CT で腫瘍は，右舌根部から 舌，口腔底へ，また中咽頭側壁にまで及び，後 方では，ほぼ正中まで腫大していた。また右頸 
部へのリンパ節転移を認めた（図 1)。胸部レン トゲン写真では, 両肺野に多発性転移と肺門リ ンパ節の腫大を認めた。腹部 CT で左腎は摘出 してあり，局所再発は無く，肝転移や傍大動脈 リンパ節腫大も認めなかった。

病理所見: 摘除腎癌組織像は, 細胞質に富み, 核が比較的小型で均一な clear cell carcinoma の増生像が見られ，Grawitz 腫瘍明細胞亜型と 診断された(図 2)。これに対し，1989年 1 月11 日に生検を行った舌根部腫痬の組織像は, 腎の clear cell carcinoma の組織像と非常に類似し た像を呈していた(図 3 )。PAS染色では, 唾 液腺の clear cell carcinoma の特徵である粘液 成分は認めず，またビィンチン染色にて，腎癌

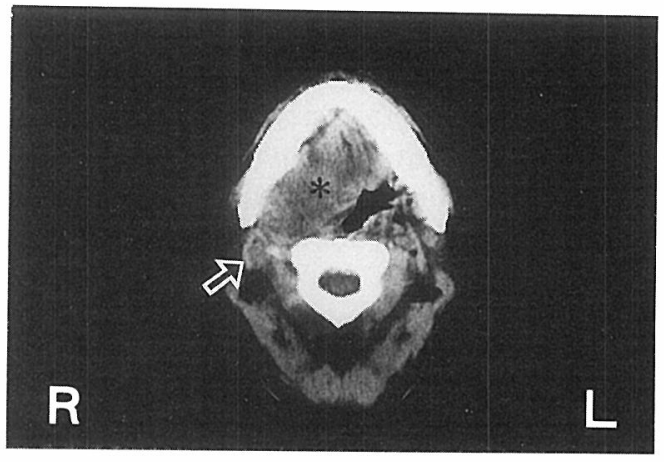

図 1 頸部 CT

右舌口腔底より中咽頭側壁への腫瘍浸潤(*) と, 右頸部リンパ節移転(ら)を認める.
に执いて比較的よく見られるビメンチンが多数 認められた。以上ょり Grawitz 腫瘍の舌根部 転移と診断された。

経過：1985年より多発性肺転移があることや， 初診時に舌根部の腫瘍が進展していたため, 根 治手術としての舌転移巣切除術は行わず, 舌腫 瘍よりの出血や疼痛が強いため1990年 2 月 15 日 cryosurgeryを行った。

手術時所見 : 舌根部の術後の浮腫性腫脹によ る気道閉塞の可能性があるため，局麻下に気管 切開を行い，気切孔から插管し，全身麻酔下儿 cryosurgeryを行った。 $-100^{\circ} \mathrm{C} て ゙ 30$ 秒〜 60秒 間, 6 力所, 腫瘍を周囲正常組織を含め凍結し た(図 4 ).

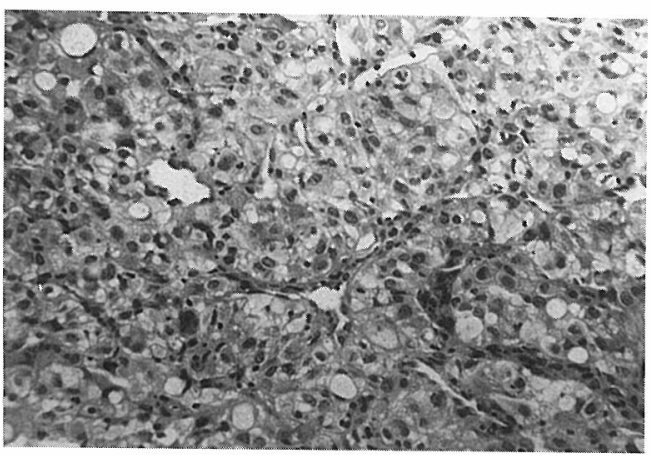

図 3 舌根部腫瘍病理組織像

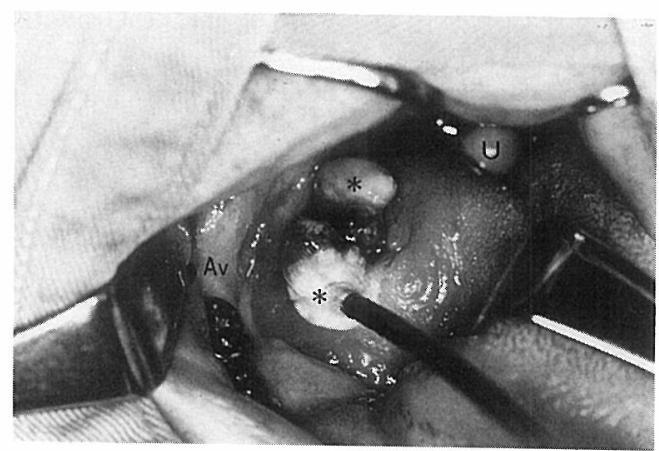

図 4 術中写真

凍結した組織が白く変色して ice ball となってい る. (U：口蓋垂 $\mathrm{Av}$ : 歯槽突起 * : ice ball) 
術後経過：泌尿器科でインターフェロンの投 与を受け, 術後 3 週までは舌よりの出血は無く 経過良好であった。 しかし，4月末ょり肺炎と 無気肺を併発し, 徐々に全身状態不良となり 8 月24日呼吸不全のため死亡した。死亡直前の所 見としては, 舌根部腫瘍は喉頭蓋谷の右側 $3 / 4$ を占め喉頭蓋を軽度圧排していた。

\section{考察}

転移性舌悪性腫瘍の報告は稀であり12), 悪 性腫瘍患者の剖検例の $0.1 \sim 0.2 \%$ に認められる の久である314)。また，転移性舌悪性腫瘍中の Grawitz 腫瘍の頻度を, Weitzner ら ${ }^{3)}$ は，15例 中 3 例 $(20 \%)$ と報告している.

表 1 Grawitz 腫瘍の耳鼻咽喉科領域転移 （里見佳昭,他：19746) より転載）

\begin{tabular}{l|r|r}
\hline \hline 転移部位 & 例数 & $\%$ \\
\hline \hline 鼻・副鼻腔 & 24 & 38 \\
咽頭 & 8 & 13 \\
上頢骨 & 6 & 9 \\
下顎·骨 & 6 & 9 \\
耳 & 5 & 8 \\
茵肉 & 4 & 6 \\
舌 & 3 & 5 \\
扁桃 & 3 & 5 \\
その他 & 5 & 8 \\
\hline
\end{tabular}

Grawitz 腫瘍は，転移を起こしやすい腫瘍で あり, 原発巣に比べ転移巣の発育が速く, 転移 巣が先に発見されることも少なくない1)。転移 部位は肺, リンパ節, 骨, 肝の順に多く, 他に 脳, 脾, 副腎, 皮膚や耳鼻咽喉科領域への転移 も報告されている5)6)，里見ら ${ }^{6)}$ は，Grawitz 腫 瘍の耳鼻咽喉科領域への転移は124例中 4 例 ( 3 \%)であり，稀ではなく腎癌の転移しやすい部 位として認識しなければならないと述べている。 また，耳鼻咽喉科領域への転移症例64例を集計 し, 最も転移の多い部位は鼻副鼻腔の $38 \%$ であ り, 舌への転移は $5 \%$ と述べている(表 1$)^{6}$. 我々の検索しえた範囲では，本邦で Grawitz 腫瘍の舌への転移は，本症例を含め 7 例であり， このらち舌根部に発生したものは 3 例であった (表 2 ). 以下これらの症例について考察する.

年齢は, 41歳から77歳(平均年齢59.6歳)で, 性別は，男：女＝4：3 で性差は認めなかった。 舌転移部位は, 舌背が 4 例, 舌根が 3 例でめり, 舌癌の好発部位である舌縁への発生は認めなか った。

Grawitz 腫瘍の組織型は, 明細胞亜型, 顆粒 細胞亜型, 混合細胞亜型, 紡鍾細胞亜型, 多形 細胞亜型に分類される. 舌転移症例の組織型は 明細胞亜型 4 例, 多形細胞亜型 1 例, 記載なし 2 例であった. Grawitz 腫瘍の明細胞亜型は, 唾液腺原発の clear cell carcinoma との鑑別が 必要とされている1)。本症例では, 舌根部腫瘍

表 2 Grawitz 腫瘍舌転移報告例

\begin{tabular}{|c|c|c|c|c|c|c|c|c|}
\hline 報告者 & 年齢 & 性 & 部位 & 大きさ & 組織垔型 & 転 移 & 舌転移治療 & 予 後 \\
\hline 里 見 & 41 & 女 & 舌背 & $1.7 \times 1.3 \mathrm{~cm}$ & 不 明 & (1) 肺 (2)舌 & なし & 1 力月 \\
\hline 北 尾 & 57 & 男 & 舌根 & $2.1 \times 1.5 \mathrm{~cm}$ & 明細胞 & (1) 肺 (2)舌 & 摘出術 & 不明 \\
\hline 飯 尾 & 77 & 女 & 舌背 & $3 \times 3 \quad \mathrm{~cm}$ & 不 明 & (1) 肺 (2)舌 & なし & 2 力月 \\
\hline 山 本 & 57 & 男 & 舌背 & 小指頭大 & 明細胞 & 舌・肺・腸 & 不明 & 不明 \\
\hline 稲 井 & 42 & 男 & 舌根 & $3 \times 3 \quad \mathrm{~cm}$ & 多形細胞 & 舌 - 肺 & 放射線 - 化学 & 7 力月 \\
\hline 松 本 & 77 & 女 & 舌背 & $3 \times 3 \quad \mathrm{~cm}$ & 明細胞 & (1)肺 (2)舌 & 化学 & 2 力月 \\
\hline 本症例 & 66 & 男 & 舌根 & $4 \times 3$ & 明細胞 & (1)肺 (2)舌 & cryosurgery & 7 力月 \\
\hline
\end{tabular}


組織像は, 腎の明細胞亜型の組織像と非常に類 似しており, PAS 染色で, 唾液腺の clear cell carcinoma の特徴である粘液成分は認めず，ま たビメンチン染色にて，腎癌に扔いて比較的よ く見られるビメンチンが多数認められたことか ら Grawitz 腫瘍の舌根部転移と診断した。

転移巣の臨床的特徵は, 血流が豊富なため色 調が赤く易出血性であり7)8，腫瘍が大きくな ると拍動を触れるとされている6). 全例易出血 性であったが，色調が赤いものは 3 例 (43\%) で, 拍動性のものはなかった. 本症例は, 赤く易出 血性の腫瘍であったが，拍動性ではなかった。

舌以外への遠隔転移は，小腸への転移を 1 例， 肺転移を全例飞認めた。転移の順序は，5例が 肺転移が先行し， 1 例は舌と肺転移が同時期に 発見され，1例は舌癌診断後に腎, 腸, 肺癌が 発見されている. Grawitz 腫瘍の転移は，大部

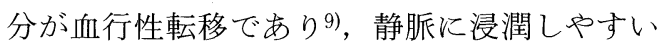
とされている10)，血行性転移の経路は腎静脈か ら卵巣または精巣静脈から逆行性に骨盤臓器一 転移するもの，Batson 椎骨静脈叢から軸骨格 へ行くもの, 下大静脈より肺へ行さ, さら飞左 室から動脈を介するものがある10)。 をた，リン パ行性転移は，所属リンパ節にとどまるものが 多い，本症例の舌への転移経路は，左腎静脈へ 腫瘍浸潤があることや, 肺転移後 4 年経過して 舌転移が発見されている事から，血行性に肺転 移を起し, 肺転移巣から舌根へ血行性転移した ものと考えられた。

舌転移に対する治療は, 根治手術 1 例, 姑息 的手術 1 例, 化学療法 1 例, 放射線と化学療法 の併用 1 例，治療なし 2 例，不明が 1 例であっ た。

舌転移巣の治療方針は，舌転移巣の進行程度， 全身状態, 他の転移巣の有無・進行程度に上り 決められる. Grawitz 腫瘍の転移巣に対する治 療は, 切除可能なら手術を積極的に行ら傾向に あり ${ }^{9)}$ ，他に転移巣がない場合や，他に転移巣 が存在しても進行の遅い場合は, 根治手術(舌 転移巣切除術)の適応となる。しかし, 他の転
移巣の進行の速いものや，進行して発見された ものは，姑息的治療とならざるをえない。

姑息的治療には, cryosurgery やレーザー手 術といった手術療法や放射線療法, 化学療法が ある. 放射線療法や化学療法は, 通常予後を延 長しないとされている6). しかし稲井ら7) は， 多形細胞亜型に, 放射線療法と化学療法 (adriamycin, cisplatin, cyclophosphamide) を併用し 舌転移巣が消失した症例を報告し，明細胞亜型 は，放射線療法，化学療法が無効なことが多い が，組織覀型によっては有効であると述べてい る. 本症例は, 舌転移巣が進行しており, 摘出 には大きな侵襲が必要なことや，肺転移が進行 していることから根治手術の適応とはならなか った，放射線療法は，腫瘍よりの出血の恐れが あり,ささら組織亜型が明細胞亜型である事か ら, 放射線療法や化学療法は効果が少ないと考 えられた。このため，除痛と止血を目的とし， cryosurgeryを行った。 cryosurgeryは，病変 が深在性の場合や, 深部まで達している時は, 手術効果が深部に及ばない欠点はあるが，手術 侵襲が少なく反復して行うことができ，悪性腫 瘍の他に，局所の毛細血管を閉塞することから 出血性疾患へも適応されている11). 我々の症例 でも除痛といら点では, ある程度の目的を達し ていたものと考光られる。

舌転移発見後の生存期間は， 2 例の生存例を 除き平均 3.8 力であり, 全例肺転移のために 死亡している. 生存例も報告後の生存期間は不 明であり, 肺転移は進行して未り予後不良と思 われる。本症例も肺転移による呼吸不全のため, 舌転移発見後 7 カ月で死亡した。

\section{まとめ}

Grawitz 腫瘍で左側腎摘出後, 肺転移をきた し，化学療法中に舌根部腫瘍が出現した66歳男 性症例を経験した。治療は, 疼痛と出血に対し て cryosurgery を対症的に行ったが，肺転移巣 に上る呼吸不全のため, 舌根転移発見後 7 力月 で死亡した，症例を報告し若干の考察を加えた。 
本論文の要旨は, 第15回日耳鼻中国四国地方部会 (高知)に拈いて口演した。

\section{文献}

1) 北尾健二郎, 渡辺 敬, 宮村健一郎, 他 : 舌根 に転移した Grawitz 腫瘍の 1 症例. 耳喉 58 ： $67 \sim 70,1986$.

2) 中田将風, 山下隆司, 渡部雄二, 他 : 舌根部腫 瘍で発症した内分泌非活性副腎皮質癌の 1 例. 癌の臨床 $32 ： 1855 \sim 1859,1986$.

3) Weitzner S, Hentel W and Albuquerque NM : Metastatic carcinoma in tongue. Oral Surg $25: 278 \sim 281,1968$.

4) Zegarelli DJ, Tsukuda Y, Pickren JW, et al : Metastatic tumor to the tongue; report of twelve cases. Oral Surg $35: 202 \sim 211,1973$.

5）松本充司, 飯尾昭三 : 腎癌舌転移の 1 例. 西日 泌尿 $49: 1147 \sim 1149,1987$.

6）里見佳昭，松浦謙一，小川 英，他：腎癌の耳 鼻咽喉科領域 (耳下腺, 鼻腔, 舌, 歯肉) への転 移症例. 臨泌 $28: 611 \sim 616,1974$.
7）稲井 徹, 香川 征, 淡河洋一, 他 : 舌転移を きたした腎細胞癌の 1 例. 泌尿紀要 $33: 1240$ 〜 1243, 1987.

8）中島成人, 隈上秀伯：蝶形骨洞执よび多発性骨 転移を来たした腎腫瘍 (Grawitz’s Tumor) 例.

耳鼻 $24: 198 \sim 204,1978$.

9）三杉和章, 里見佳昭 : 腎腫瘍. 現代病理学大系 15B (飯島宗一編)．173～210頁，中山書店，東 京, 1986.

10）梅田敬子, 馬場駿吉, 横田 明, 他：腎癌によ る口蓋扁桃転移癌の 1 例. 日扁桃誌 $24: 113 \sim$ $116,1985$.

11）石山英一, 山崎守勝, 増田喜信 : 耳鼻咽喉科領 域に扣けるCryosurgeryの適応症ついて。日 耳鼻 $78: 237 \sim 248,1975$.

$\left(\begin{array}{l}\text { 原稿受付 : 平成 } 3 \text { 年 } 1 \text { 月 } 25 \text { 日 } \\ \text { 原稿採択 : 平成 } 3 \text { 年 } 3 \text { 月 } 19 \text { 日 } \\ \text { 別刷請求先 : 小田一成 } \\ \text { 我 } 734 \text { 広島市南区霞1-2-3 } \\ \text { 広島大学医学部耳鼻咽喉科学教室 }\end{array}\right)$

